\title{
The syndromes of reduced sensitivity to thyroid hormone - the current state of art
}

Anna Cyniak-Magierska, $\stackrel{\text { Affl }}{\text { Cont }}$

Corresponding Affiliation: $\underline{\text { Aff1 }}$

\begin{tabular}{|c|c|}
\hline \multicolumn{2}{|r|}{ ArticleInfo } \\
\hline ArticleID & 193 \\
\hline ArticleDOI & 10.1186/1756-6614-8-S1-A5 \\
\hline ArticleCitationID & A5 \\
\hline ArticleSequenceNumber & 5 \\
\hline ArticleCategory & Meeting abstract \\
\hline ArticleFirstPage & 1 \\
\hline ArticleLastPage & 3 \\
\hline ArticleHistory & $\begin{array}{ll}\text { RegistrationDate } & : 2015-6-22 \\
\text { OnlineDate } & : 2015-6-22\end{array}$ \\
\hline ArticleCopyright & $\begin{array}{l}\text { Cyniak-Magierska; licensee BioMed Central Ltd.2015 } \\
\text { This article is published under license to BioMed Central } \\
\text { Ltd. This is an Open Access article distributed under the } \\
\text { terms of the Creative Commons Attribution License } \\
\text { (http://creativecommons.org/licenses/by/4.0), which permits } \\
\text { unrestricted use, distribution, and reproduction in any } \\
\text { medium, provided the original work is properly cited. The } \\
\text { Creative Commons Public Domain Dedication waiver } \\
\text { (http://creativecommons.org/publicdomain/zero/1.0/) applies } \\
\text { to the data made available in this article, unless otherwise } \\
\text { stated. }\end{array}$ \\
\hline
\end{tabular}

Aff1

Department of Endocrinology and Metabolic Diseases, Polish Mother's Memorial Research Institute, The Medical University of Lodz, Lodz, Poland

Spring School of Thyroidology organized by the Polish Thyroid Association 2014: abstracts of invited lectures

Spring School of Thyroidology organized by the Polish Thyroid Association 2014

Miedzyzdroje, Poland

23-24 May 2014

Publication of this supplement was funded by the Polish Thyroid Association. The Supplement Editors declare that they have no competing interests.

Meeting abstracts

Andrzej Lewinski

Mariusz Stasiolek 
The clinical, laboratory, genetic and molecular characteristics of syndromes of reduced sensitivity to thyroid hormone are the subject of this abstract.

The syndrome of reduced sensitivity to thyroid hormone in the majority of cases is caused by point mutations in the thyroid hormone receptor $\beta(\mathrm{T} R \beta)$ gene. Before $T R \beta$ gene mutations were recognized, resistance to thyroid hormone (RTH) was subdivided on clinical basis into generalized, isolated pituitary and peripheral tissue. Nowadays this classification has a clinical usefulness, but it seems to have no logical etiologic grounds. The mutations in TR $\beta$ gene have been found in over 3000 individuals belonging to approximately 1000 families. While the clinical presentation is variable, the main features are: high serum $\mathrm{FT}_{4}$ and usually also $\mathrm{FT}_{3}$ concentrations, non-suppressed - sometimes slightly elevated serum thyrotropin (TSH), commonly a goiter. The majority of subjects have a near normal metabolic state, sometimes coexistence of clinical symptoms of thyroid hormones deficiency and excess takes place in one patient. Thus, delayed growth and bone maturation, and learning disabilities can be present along with hyperactive behavior and sinus tachycardia. Mental retardation was found in $3 \%$ of cases. Attention deficit hyperactivity disorder (ADHD) is also present in about half of patients with RTH syndrome.

In $15 \%$ of families with RTH symptoms no mutations in the $T R \beta$ gene were found. The term nonTR-RTH refers to this subgroup of individuals, clinically and biochemically identical with RTH caused by TR $\beta$ mutations.

Recently, mutations in TR 1 gene have been described in two families. First nonsense mutation produces a truncated TR $\alpha 1$ (E403X) that lacks the C-terminal $\alpha$-helix. It has been identified in a 6 year-old girl with chronic constipation, and growth and developmental delay. Another family with TR $\alpha$ gene mutation was described in 2012. In both cases, thyroid function tests were distinct from those in classical RTH with TR $\beta$ gene mutations. These patients had low serum $\mathrm{T}_{4}$, high $\mathrm{T}_{3}$, and very low $\mathrm{rT}_{3}$.

Two relatively novel syndromes presenting reduced sensitivity to thyroid hormone: membrane transport defect and thyroid hormone metabolism defect were described. This led to the broadening of the definition of reduced sensitivity to thyroid hormone to encompass all the defects that can interfere with the biological activity of a chemically intact hormone, secreted in normal amounts. Thyroid hormone cell membrane transporter defect (THCMTD) is caused by mutations in the MCT8 gene. It is an X-linked defect. Mutations have $100 \%$ penetrance in males who manifest both neuropsychomotor impairment and characteristic thyroid test abnormalities (high serum $\mathrm{T}_{3}$, low $\mathrm{rT}_{3}$, low normal or reduced $\mathrm{T}_{4}$ with slightly elevated $\mathrm{TSH}$ level). The defect of the intracellular metabolism of thyroid hormones (THMD) is caused by mutations in the SECISBP2 gene who is required for the synthesis of selenoproteins, including thyroid hormone deiodinases. It was described in 10 patients from 8 families.

\section{References}

1. Refetoff S, De Wind LT, DeGroot LJ: Familial syndrome combining deaf-mutism, stippled epiphyses, goiter, and abnormally high PBI: possible target organ refractoriness to thyroid hormone. J Clin Endocrinol Metab 1967,27(2):279-294. 10.1210/jcem-27-2-279

2. Refetoff S, Dumitrescu A: Syndromes of reduced sensitivity to thyroid hormone: genetic defects in hormone receptors, cell transporters and deiodination. Best Pract Res Clin Endocrinol Metab 2007,21(2):277-305. 10.1016/j.beem.2007.03.005

3. Dumitrescu A, Refetoff S: The syndromes of reduced sensitivity to thyroid hormone. Biochim Biophys Acta 2013,1830(7):3987-4003. 10.1016/j.bbagen.2012.08.005

4. Bochukova E, Schoenmakers N, Agostini M, Schoenmakers E, Rajanayagam O, Keogh JM, et al.: A mutation in the thyroid hormone receptor alpha gene. $N$ Engl J Med 2012,366(3):243-249. 10.1056/NEJMoa1110296

5. Van Muellem A, Van Heerebeek R, Chrysis D, et al.: Clinical phenotype and mutant TRalpha1. $N$ Engl J Med 2012, 366: 1451-1453. 
6. Maranduba CM, Friesema EC, Kok F, Kester MH, Jansen J, Sertie AL, et al.: Decreased cellular T3 uptake and metabolism in Allan-Herndon-Dudley syndrome (AHDS) due to a novel mutation in the MCT8 thyroid hormone transporter. $J$ Med Genet 2006,43(5):457-460.

7. Dumitrescu AM, Liao XH, Abdullah MS, Lado-Abeal J, Majed FA, Moeller LC, et al.: Mutations in SECISBP2 result in abnormal thyroid hormone metabolism. Nat Genet 2005,37(11):1247-1252. $10.1038 / \mathrm{ng} 1654$ 